Int. J. Electrochem. Sci., 12 (2017) $1348-1361$

International Journal of

ELECTROCHEMICAL

SCIENCE

www.electrochemsci.org

\title{
Effect of Passivation Potential on Passive Behavior and Corrosion Resistance of Ni-Cu-P Amorphous Coating in Alkaline Solution
}

\author{
Jie Chen ${ }^{1}$, Yong Zou ${ }^{1, *}$, Kenji Matsuda ${ }^{2}$, Guanlin Zhao ${ }^{1}$ \\ ${ }^{1}$ Key Lab of Liquid Structure and Heredity of Materials, Ministry of Education, Shandong University, \\ Jinan 250061, Shandong, China. \\ ${ }^{2}$ Department of Materials Science and Technology, Faculty of Engineering, University of Toyama, \\ Toyama, 930-8555, Japan. \\ *E-mail: yzou@sdu.edu.cn
}

doi: $10.20964 / 2017.02 .04$

Received: 23 October 2016/ Accepted: 12 December 2016 / Published: 30 December 2016

Corrosion resistance and passive behavior of electroless $\mathrm{Ni}-\mathrm{Cu}-\mathrm{P}$ amorphous coating have been investigated in $10 \mathrm{wt} \% \mathrm{NaOH}$ solution by using electrochemical impedance spectroscopy, MottSchottky and X-ray photoelectron spectroscopy analysis. The result that the corrosion resistance is increased firstly and then exhibits an opposite trend with the increasing passive potential is resulted from the variation of passive film on the coating. Passive films formed at lower potential possess $\mathrm{n}-$ type and p-type bipolar semiconductors characteristics, but the passive films formed at higher potential have only $\mathrm{p}$-type semiconductor characteristics. The thickness of passive films was increased with the increase of passive potential. The corrosion resistance of passivation films is combined affected by their thickness and their semiconductor type.

Keywords: Ni-Cu-P; Amorphous coating; Corrosion resistance; Passive films; XPS

\section{$\underline{\text { FULL TEXT }}$}

(C) 2017 The Authors. Published by ESG (www.electrochemsci.org). This article is an open access article distributed under the terms and conditions of the Creative Commons Attribution license (http://creativecommons.org/licenses/by/4.0/). 